\title{
Botryosphaeriaceae Fungi as Causal Agents of Dieback and Corky Bark in Rambutan and Longan
}

\author{
L. M. Serrato-Diaz, ${ }^{1}$ A. Aviles-Noriega, ${ }^{2}$ A. Soto-Bauzó, ${ }^{1}$ L. I. Rivera-Vargas, ${ }^{2}$ R. Goenaga, ${ }^{3, \dagger}$ and P. Bayman ${ }^{1}$ \\ ${ }^{1}$ Department of Biology, University of Puerto Rico \\ ${ }^{2}$ Department of Agro-Environmental, University of Puerto Rico \\ ${ }^{3}$ United States Department of Agriculture-Agricultural Research Service, Tropical Agriculture Research Station
}

\begin{abstract}
Fungi in the Botryosphaeriaceae family cause dieback, fruit rots, and stem cankers in many tropical fruit trees. To identify which species of Botryosphaeriaceae were present in tropical fruit in Puerto Rico and the symptoms they cause in rambutan and longan, a disease survey was conducted throughout the island from 2008 to 2016. Diseased organs of rambutan, longan, mango, and tangerine were collected and 39 isolates belonging to the Botryosphaeriaceae family were isolated and identified. Phylogenetic analysis of three nuclear genes identified nine species: six Lasiodiplodia spp. and three Neofusicoccum spp. All 39 isolates were inoculated on healthy 1-year-old rambutan and longan seedlings to confirm their pathogenicity. Dieback on both rambutan

theobromae, Neofusicoccum batangarum, and N. parvum) caused dieback in rambutan. Five of these pathogenic isolates were collected from rambutan, four from longan, two from mango, and three from tangerine. Ten isolates of four Lasiodiplodia spp. caused dieback in longan: L. hormozganensis, L. iraniensis, L. pseudotheobromae and L. theobromae,. Of these, three were collected from rambutan, three from longan, one from mango, and three from tangerine. Abundant development of pycnidia on branches, called corky bark, were observed on both rambutan and longan 60 DAI. Cross-inoculations showed that pathogenicity is wide in spectrum, indicating that different planting alternatives should be considered for better crop management.
\end{abstract} and longan was observed at 14 days after inoculation (DAI). Fourteen isolates from seven Botryosphaeriaceae species (Lasiodiplodia brasiliensis, L. hormozganensis, L. iraniensis, L. pseudotheobromae, $L$.
Keywords: fruit, fungi, pathogen detection, pathogen diversity, tree fruit, tropical plants
Rambutan (Nephelium lappaceum L.) and longan (Dimocarpus longan L.) are exotic tropical trees in the family Sapindaceae. Native to Southeast Asia, they are popular worldwide for their fruit. In 2017, global rambutan and longan production was estimated at 3.4 and 1.4 million tons, respectively (Altendorf 2018). The major producers were Indonesia and Thailand for rambutan, and China and Thailand for longan (Altendorf 2018). In the United States, production is concentrated in Hawaii and Puerto Rico for rambutan and in California, Florida, and Hawaii for longan (Crane et al. 2005; Goenaga and Jenkins 2011).

Diseases of rambutan and longan affect fruit, stems, leaves, and inflorescences (Chamswarng et al. 2012; Nishijima et al. 2002; Rossman et al. 2007, 2012; Sangchote et al. 1998; Serrato-Diaz et al. 2011, 2014b, 2015a). Fruit rot is the most important disease in rambutan and is reported to cause up to $30 \%$ yield losses in pre and postharvest (Farungsang et al. 1992; Nishijima et al. 2002; Pordesimo and Luna-Ilag 1982; Sangchote et al. 1998; Sivakumar et al. 1997, 2000). It is caused by a complex of pathogenic fungi that include Calonectria hongkongensis, Colletotrichum spp., Diaporthe sp., Gliocephalotrichum spp. Lasmenia sp., Lasiodiplodia theobromae, and Pestalotiopsis sp. (Farungsang et al. 1992; Lombard et al. 2014; Nishijima et al. 2002; Pordesimo and Luna-Ilag 1982; Ploetz 2003; Sangchote et al. 1998; Serrato-Diaz et al. 2011, 2012, 2013a,b, 2015b, 2017; Sivakumar et al. 1997, 2000). Diseases in longan have been less studied. Fruit rot caused by L. theobromae is the most important disease, and has been reported in China, Puerto Rico, and Thailand (Sardsud et al. 1998; Serrato-Diaz et al. 2014b; Sun

${ }^{\dagger}$ Corresponding author: R. Goenaga;

ricardo.goenaga@usda.gov

The author(s) declare no conflict of interest.

Accepted for publication 28 July 2019.

This article is in the public domain and not copyrightable. It may be freely reprinted with customary crediting of the source. The American Phytopathological Society, 2020. et al. 2018). Other diseases such as sooty molds on fruit, inflorescence blight, and vascular and flower necrosis have also been reported affecting longan (Serrato-Diaz et al. 2010, 2014b, 2015a).

Another severe disease of the Sapindaceae family is corky bark. It is associated with stem canker and, in severe cases, dieback on branches (Booth and Ting 1964; Rossman et al. 2010). Corky bark of Sapindaceae trees was originally reported from Malaysia (Booth and Ting 1964), and later from Honduras, Hawaii, and Puerto Rico, (Rossman et al. 2007, 2010, 2012). The only pathogen reported for corky bark is Dolabra nepheliae C. Booth \& W. P. Ting. (class Dothideomycetes).Although the fungus was reported in 1964 in Malaysia and eventually in Honduras, Hawaii, and Puerto Rico, Koch's postulates have not been fulfilled. Therefore, whether or not this fungus causes any of the symptoms attributed and observed in the field remains to be validated (Booth and Ting 1964; Rossman et al. 2007, 2010, 2012).

Worldwide, species in the Botryosphaeriaceae family have been reported to cause stem cankers and dieback in tropical and subtropical fruit such as almond, avocado, citrus, grapevine, mamey sapote, mango, mangosteen, and pistachio, as well as rambutan and longan (Adesemoye et al. 2014; Burruano et al. 2008; Inderbitzin et al. 2010; Ismail et al. 2012; Javier-Alva et al. 2009; MAG 2007; McDonald and Eskalen 2011; Michailides et al. 2002; Muhammad et al. 2009; Sakalidis et al. 2011; Sardsud et al. 1998; Úrbez-Torres et al. 2009; Vazquez-Lopez et al. 2009; Zea-Bonilla et al. 2007). Mango and citrus are the tropical crops most affected by the Botryosphaeriaceae family: around 14 species of Botryosphaeriacae have been reported in mango causing dieback, stem end rot, and gummosis and 10 species have been identified from dieback, bot gummosis, and canker in citrus (Abdollahzadeh et al. 2013; Adesemoye et al. 2014; Marques et al. 2013a,b; Mayorquin et al. 2016; Polizzi et al. 2009; Sakalidis et al. 2011).

In surveys conducted in Puerto Rico from 2008 to 2013, samples of diseased tissue of mango, rambutan, and longan showing symptoms of fruit rot, inflorescence blight, leaf blight, dieback, and rachis necrosis were collected. From this survey, 260 fungal isolates in the Botryosphaeriaceae family were identified, suggesting that they play an important role in tropical plant diseases and 
potentially could be the causative agents of dieback in rambutan and longan, as well as in other fruit crops (Serrato-Diaz et al. 2013c).

The purpose of this study was to identify species of Botryosphaeriaceae from rambutan and longan and test whether they can cause dieback and corky bark. Also, we hypothesized that these fungi can cause cross-infection, with fungal isolates from one tropical fruit crop able to cause disease in others crops.

\section{Materials and Methods}

Collection of plant material and isolation of Botryosphaeriaceae spp. Isolates of Botryosphaeriaceae from rambutan (60 randomly selected trees from six plots), longan (60 randomly selected trees from six plots), mango (1,500 randomly selected trees from a germplasm collection), and tangerine ( 2 randomly selected trees from an experiment) showing dieback, fruit rot, inflorescence blight, and leaf blight were collected throughout Puerto Rico from 2008 to 2016, as reported by Serrato-Diaz et al. (2013c). Sampling effort was inconsistent; members of the Botryosphaeriaceae family and other fungi were also isolated. Isolations were done according to Serrato-Diaz et al. (2013c).

Diseased plant tissues of rambutan, longan, mango, and tangerine were disinfested with $70 \%$ ethanol, rinsed with sterile deionizeddistilled water for $1 \mathrm{~min}$, and plated on potato dextrose agar (PDA) amended with streptomycin at $0.125 \mathrm{~g} /$ liter and ampicillin at 0.25 $\mathrm{g} /$ liter. Purified isolates were grown in potato dextrose broth and mycelium was collected after 8 days for DNA extraction.

DNA extraction, PCR, and sequencing. Genomic DNA was extracted from 39 fungal isolates using the Dneasy Plant Mini Kit (Qiagen). DNA was amplified from regions of three nuclear genes: the internal transcribed spacer (ITS)1-5.8S-ITS2 (ITS) region of the nuclear ribosomal DNA, the $\beta$-tubulin gene ( $\beta$ tub), and the transelongation factor $1-\alpha$ gene $(E F 1-\alpha)$. The ITS region was amplified using primer pair ITS1/ITS4 (White et al. 1990). The partial sequences of the $\beta$ tub and EF1- $\alpha$ genes were amplified using primer pairs Bt2a/Bt2b for $\beta$ tub and EF1-728F/EF1-986R and EF1-688F/ EF1-1251R for EF1- $\alpha$ (Alves et al. 2008; Carbone and Kohn 1999; Glass and Donaldson 1995). PCRs using Amplitaq Gold (Applied Biosystems) were conducted according to Alves et al. (2004). PCR products were purified using QIA Quick PCR Kit (Qiagen) and sequenced at the Sequencing and Genotyping Facility at the University of Puerto Rico. Sequences were edited using Sequencher (version 5.0; Gene Codes Corporation) and deposited in NCBI GenBank (Table 1).

Phylogenetic inference. Phylogenetic trees were constructed using sequences from 39 isolates of Botryosphaeriaceae and extype specimens for Neofusicoccum spp. and Lasiodiplodia spp. (Table 2) (Yang et al. 2017). Diplodia mutila ex-type CBS 112553 and D. seriata ex-type CBS 112555 were added as outgroups

Table 1. Source of isolates and accession numbers for sequences of internal transcribed spacer (ITS)1-5.8S-ITS2, $\beta$-tubulin, and transelongation factor EF1- $\alpha$ genes of Botryosphaeriaceae used in this study

\begin{tabular}{|c|c|c|c|c|c|c|}
\hline \multirow[b]{2}{*}{ Isolates } & \multirow[b]{2}{*}{ Fungal species } & \multirow[b]{2}{*}{ Symptom $^{\mathbf{a}}$} & \multirow[b]{2}{*}{ Source } & \multicolumn{3}{|c|}{ GenBank accession numbers } \\
\hline & & & & ITS & $\beta$-Tubulin & EF1- $\alpha$ \\
\hline 2. BO2-PRRF35 & Neofusicoccum parvum & Fruit rot & Rambutan & MK282737 & MK294088 & MK294155 \\
\hline 6.BO6-PRRF64 & N. parvum & Fruit rot & Rambutan & MK282739 & MK294090 & MK294157 \\
\hline 49.Bt8-RH23B & Lasiodiplodia iraniensis & Leaf blight & Rambutan & MK282716 & MK294105 & MK294134 \\
\hline 50.Bt9-RH25 & L. iraniensis & Leaf blight & Rambutan & MK282717 & MK294106 & MK294135 \\
\hline 52.Bt21-RH8 & L. iraniensis & Leaf blight & Rambutan & MK282718 & MK294107 & MK294136 \\
\hline 78.Bt23-RC8C & L. pseudotheobromae & Dieback & Rambutan & MK282723 & MK294114 & MK294141 \\
\hline 80.BO8-PRRF58 & L. pseudotheobromae & Fruit rot & Rambutan & MK282725 & MK294112 & MK294143 \\
\hline 97.BO11-PRRF54 & L. parva & Fruit rot & Rambutan & MK282730 & MK294119 & MK294148 \\
\hline 253.RFISAB4 & N. batangarum & Fruit rot & Rambutan & MK282731 & MK294082 & MK294149 \\
\hline 254.RFISAB2 & N. batangarum & Fruit rot & Rambutan & MK282732 & MK294083 & MK294150 \\
\hline 255.RFISAJIJ3 & N. mangiferae & Fruit rot & Rambutan & MK282738 & MK294089 & MK294156 \\
\hline 66.Bt3-RC6A & L. iraniensis & Dieback & Rambutan & MK282709 & MK294102 & MK294127 \\
\hline 68.Bt5-RC4B & L. iraniensis & Dieback & Rambutan & MK282710 & MK294103 & MK294128 \\
\hline 69.Bt6-RC2B & L. iraniensis & Dieback & Rambutan & MK282706 & MK294099 & MK294124 \\
\hline 89. PHLO6 & L. pseudotheobromae & Inflores & Longan & MK282724 & MK294113 & MK294142 \\
\hline 105.PHLO9 & L. theobromae & Inflores & Longan & MK282714 & MK294094 & MK294132 \\
\hline 115.FLLOPR1 & L. iraniensis & Inflores & Longan & MK282705 & MK294098 & MK294123 \\
\hline 122.FLLOPRC1 & L. brasiliensis & Inflores & Longan & MK282704 & MK294096 & MK294122 \\
\hline 123.FLLOPRC2 & L. brasiliensis & Inflores & Longan & MK282703 & MK294095 & MK294121 \\
\hline 124.LFPR2B & L. hormozganensis & Fruit rot & Longan & MK282729 & MK294118 & MK294147 \\
\hline 129.LFPR6B & L. hormozganensis & Fruit rot & Longan & MK282728 & MK294117 & MK294146 \\
\hline 85.PHLO2 & L. iraniensis & Inflores & Longan & MK282719 & MK294108 & MK294137 \\
\hline 140.LFPR11A & L. iraniensis & Fruit rot & Longan & MK282707 & MK294100 & MK294125 \\
\hline 113.FLLOPR3 & L. pseudotheobromae & Inflores & Longan & MK282722 & MK294111 & MK294140 \\
\hline 151.LFPR1B & L. hormozganensis & Fruit rot & Longan & MK282726 & MK294115 & MK294144 \\
\hline 152.Bt33-LFPR3 & L. iraniensis & Fruit rot & Longan & MK282708 & MK294101 & MK294126 \\
\hline 134.LFPR12A & L. hormozganensis & Fruit rot & Longan & MK282727 & MK294116 & MK294145 \\
\hline 120.FLLOPR5 & L. theobromae & Inflores & Longan & MK282711 & MK294091 & MK294129 \\
\hline 43.K15C & N. parvum & Inflores & Mango & KC631662 & KC631653 & KC631658 \\
\hline 212.FLMAISA8 & L. brasiliensis & Inflores & Mango & MK282702 & MK294097 & MK294120 \\
\hline $284.25 \mathrm{P}$ & N. batangarum & Inflores & Mango & MK282733 & MK294084 & MK294151 \\
\hline $286.129 \mathrm{~T}$ & L. iraniensis & Inflores & Mango & MK282715 & MK294104 & MK294133 \\
\hline $294.405 \mathrm{~T}$ & $N$. parvum & Inflores & Mango & MK282734 & MK294085 & MK294152 \\
\hline $295.317 \mathrm{~T}$ & N. batangarum & Inflores & Mango & MK282735 & MK294086 & MK294153 \\
\hline $302.230 \mathrm{~T}$ & N. batangarum & Inflores & Mango & MK282736 & MK294087 & MK294154 \\
\hline 310.MDBH3 & L. pseudotheobromae & Dieback & Tangerine & MK282721 & MK294110 & MK294139 \\
\hline 311.MDB51 & L. pseudotheobromae & Dieback & Tangerine & MK282720 & MK294109 & MK294138 \\
\hline 312.MDBH2 & L. theobromae & Dieback & Tangerine & MK282712 & MK294092 & MK294130 \\
\hline 313.MDBH4 & L. theobromae & Dieback & Tangerine & MK282713 & MK294093 & MK294131 \\
\hline
\end{tabular}

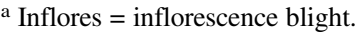


Table 2. Ex-type specimens of Neofusicoccum, Lasiodiplodia, and Diplodia spp. used in this study and their GenBank accession numbers

\begin{tabular}{|c|c|c|c|c|}
\hline \multirow[b]{2}{*}{ Species } & \multirow[b]{2}{*}{ Culture collection } & \multicolumn{3}{|c|}{ GenBank accession numbers ${ }^{a}$} \\
\hline & & ITS & EF1 & $\beta$-Tubulin \\
\hline \multirow[t]{2}{*}{ Diplodia mutila } & CBS 112553 (ex-type) & AY259093 & AY573219 & DQ458850 \\
\hline & CBS 230.30 & DQ458886 & DQ458869 & DQ458849 \\
\hline \multirow[t]{2}{*}{ D. seriata } & CBS 112555 (ex-type) & AY259094 & AY573220 & DQ458856 \\
\hline & CBS 119049 & DQ458889 & DQ458874 & DQ458857 \\
\hline \multirow[t]{3}{*}{ Lasiodiplodia brasiliensis } & CMM 4015 (ex-type) & JX464063 & JX464049 & - \\
\hline & CMM 2185 & KC484800 & KC481530 & - \\
\hline & CMM 2186 & KC484812 & KC481542 & - \\
\hline \multirow[t]{2}{*}{ L. citricola } & IRAN1522C (ex-type) & GU945354 & GU945340 & - \\
\hline & IRAN1521C & GU945353 & GU945339 & - \\
\hline \multirow[t]{2}{*}{ L. crassispora } & CBS 118741 (ex-type) & DQ103550 & EU673303 & - \\
\hline & CMW13488 & DQ103552 & DQ103558 & - \\
\hline \multirow[t]{2}{*}{ L. egyptacea } & CBS13092 (ex-type) & JN814397 & JN814424 & - \\
\hline & BOT-29 & JN814401 & JN814428 & - \\
\hline \multirow[t]{2}{*}{ L. gilanensis } & IRAN1523C (ex-type) & GU945351 & GU945342 & - \\
\hline & IRAN1501C & GU945352 & GU945341 & - \\
\hline \multirow{2}{*}{ L. gonubiensis } & CBS 115812 (ex-type) & DQ458892 & DQ458877 & DQ458860 \\
\hline & CMW14078 & AY639594 & DQ103567 & - \\
\hline \multirow[t]{2}{*}{ L. jatrophicola } & CBS 176.26 & KX464136 & KX464629 & KX464900 \\
\hline & CBS 111.13 & KX464135 & KX464628 & KX464899 \\
\hline L. hormozganensis & IRAN1500C (ex-type) & GU945355 & GU945343 & - \\
\hline & IRAN1498C & GU945356 & GU945344 & - \\
\hline L. iraniensis & IRAN921C (ex-type) & GU945346 & GU945334 & - \\
\hline & IRAN1502C & GU945347 & GU945335 & - \\
\hline L. margaritacea & CBS 122519 (ex-type) & KT852959 & KU887520 & - \\
\hline & CBS 122065 & EU144051 & EU144066 & - \\
\hline L. parva & CBS 456.78 (ex-type) & EF622083 & EF622063 & - \\
\hline & CBS 494.78 & EF622084 & EF622064 & EU673114 \\
\hline L. pseudotheobromae & CBS 116459 (ex-type) & EF622077 & EF622057 & EU673111 \\
\hline & CBS 447.62 & EF622081 & EF622060 & EU673112 \\
\hline L. rubropurpurea & WAC12535 (ex-type) & DQ103553 & EU673304 & EU673136 \\
\hline & WAC 12536 & DQ103554 & DQ103572 & - \\
\hline L. theobromae & CBS 164.96 (ex-type) & AY640255 & AY640258 & EU673110 \\
\hline & CMW9074 & AY236952 & AY236901 & AY236930 \\
\hline L. venezuelensis & WAC12539 (ex-type) & DQ103547 & EU673305 & EU673129 \\
\hline & WAC 12540 & DQ103548 & DQ103569 & - \\
\hline Neofusicoccum batangarum & CMW28363 (ex-type) & FJ900607 & FJ900653 & FJ900634 \\
\hline & CMW28320 & FJ900608 & FJ900654 & FJ900635 \\
\hline N. cordaticola & CMW13992 (ex-type) & EU821898 & EU821868 & EU821838 \\
\hline & CMW14056 & EU821903 & EU821873 & EU821843 \\
\hline N. kwambonambiense & CMW14023 (ex-type) & EU821900 & EU821870 & EU821840 \\
\hline & CMW14140 & EU821919 & EU821889 & EU821859 \\
\hline N. mangiferae & CMW7024 (ex-type) & AY615185 & DQ093221 & AY615172 \\
\hline & CMW7797 & AY615186 & DQ093220 & AY615173 \\
\hline N. parvum & CMW9081 (ex-type) & AY236943 & AY236888 & AY236917 \\
\hline & CBS 110301 & AY259098 & AY573221 & EU673095 \\
\hline N. ribis & CMW7772 (ex-type) & AY236935 & AY236877 & AY236906 \\
\hline & CMW7773 & AY236936 & AY236878 & AY236907 \\
\hline N. umdonicola & CMW14058 (ex-type) & EU821904 & EU821874 & EU821844 \\
\hline & CMW14060 & EU821905 & EU821875 & EU821845 \\
\hline N. brasiliense & CMM1285 (ex-type) & JX513628 & JX513608 & KC794030 \\
\hline & CMM1269 & JX513629 & JX513609 & KC794032 \\
\hline N. algeriense & CBS 719.85 (ex-type) & KX464151 & KX464646 & KX464921 \\
\hline & CBS 113072 & KX464150 & KX464645 & KX464920 \\
\hline N. andinum & CBS 117453 (ex-type) & AY693976 & AY693977 & KX464923 \\
\hline & CBS 117452 & DQ306263 & DQ306264 & KX464922 \\
\hline N. occulatum & CBS 128008 (ex-type) & MH864743 & EU339509 & EU339472 \\
\hline & CBS 256.80 & KX464175 & KX464696 & KX464973 \\
\hline N. pistaciarum & CBS 113083 & NR147367 & KX464712 & KX464998 \\
\hline & CBS 113084 & KX464187 & KX464713 & KX464999 \\
\hline N. arbuti & CBS 116131 & - & KF531792 & KF531793 \\
\hline & CBS 116573 & KX464153 & KX464648 & KX464925 \\
\hline N. macroclavatum & CBS 114497 & - & KX464695 & KX464972 \\
\hline N. terminaliae & CBS 125263 & MH863478 & - & KX465052 \\
\hline & CBS 125264 & GQ471805 & GQ471783 & KX465053 \\
\hline N. stellenboschiana & CBS 282.70 & KX464225 & KX464758 & KX465051 \\
\hline N. corticosae & CBS 118099 & KX464168 & KX464681 & KX464957 \\
\hline & CBS 120081 & - & KX464682 & KX464958 \\
\hline
\end{tabular}

${ }^{a}$ ITS $=$ internal transcribed spacer, $\mathrm{EF} 1=$ transelongation factor EF1- $\alpha$, and - indicates no sequences available in GenBank. 
(Phillips et al. 2013; Yang et al. 2017). Sequences were aligned using SATé (Katoh and Standley 2013) and MAFFT with RAxML for the tree estimator with 10 iterations. The three genes were concatenated using Sequence Matrix to give 1,412 and 1,453 characters for Neofusicoccum and Lasiodiplodia spp., respectively, including alignment gaps. Maximum-likelihood trees were constructed to infer the phylogeny of the Botryosphaericaeae family using RAxML with GTRCAT as the default model, $25 \gamma$ categories, and the automatic Bootstrap MRE implemented in CIPRES Science Gateway portal (Miller et al. 2010; Stamatakis 2006a,b).

Pathogenicity tests. Cross inoculations using 39 isolates of Botryosphaeriaceae (collected from rambutan, longan, mango, and tangerine showing dieback symptoms) were performed on 246 healthy 1-year-old rambutan and longan seedlings (Table 1). A first group of rambutan and longan seedlings (42 seedlings each) was inoculated only with isolates collected from their respective original host (14 isolates for rambutan and 14 for longan). A second group of 75 rambutan seedlings was inoculated with 14 isolates collected from longan, 7 isolates from mango, and 4 isolates from tangerine. A third group of 75 longan seedlings was inoculated with 14 isolates from rambutan, 7 from mango, and 4 from tangerine. Three seedlings per isolate were inoculated with 5-mm mycelial disks from pure 8-day-old cultures on PDA (Serrato-Diaz et al. 2014a,b). Twelve control seedlings were inoculated with PDA disks only. Each seedling was wounded with a scalpel on two lateral branches and the main trunk. Mycelial disks containing the fungus were placed directly on the wounds. Seedlings were kept in a humid chamber using plastic bags for 8 days under greenhouse conditions and observed for dieback at $8,14,30$, and 60 days after inoculation (DAI).

Differences between longan and rambutan in number of isolates causing dieback were tested for significance using Fisher's exact test. Differences among isolation sources (both host species and host organ from which isolates were obtained) and number of isolates causing dieback were tested for significance using exact contingency tests. For these tests, data from the three inoculation groups were combined.

\section{Results}

Phylogenetic inference. The best trees obtained with maximumlikelihood showed nine clades corresponding to three Neofusicoccum spp. and six Lasiodiplodia spp. In the Neofusicoccum phylogenetic tree (Fig. 1), five isolates clustered with the Neofusicoccum

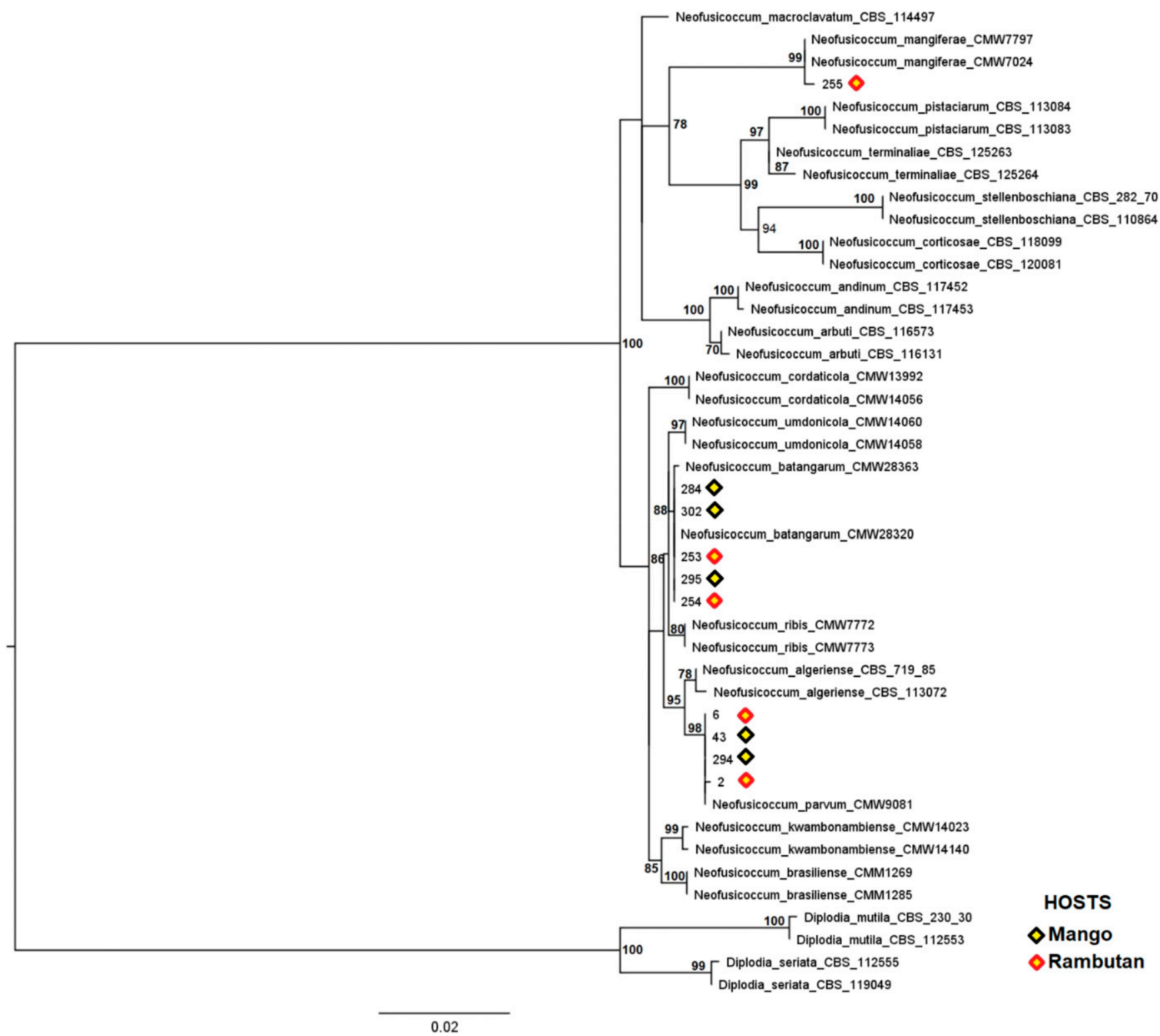

Fig. 1. Best maximum-likelihood tree of genus Neofusicoccum based on the concatenated sequences of $\beta$-tubulin, internal transcribed spacer, and translation elongation factor EF1- $\alpha$. Bootstrap support values are shown at the nodes and isolates and hosts used in this study are marked. The tree was rooted to the outgroups Diplodia seriata (CBS 119049 and CBS 112555) and D. mutila (CBS 230.30 and CBS 112553). 
batangarum clade (bootstrap support $[\mathrm{BS}]=88$ ), four with the $N$. parvum clade $(\mathrm{BS}=98)$, and one in the $N$. mangiferae clade $(\mathrm{BS}=$ 99). In the Lasiodiplodia tree (Fig. 2), 4 isolates clustered with the L. hormozganensis clade (BS = 80), 4 with the L. theobromae clade (BS = 81), 3 with the L. brasiliensis clade (BS =99), 11 with the L. iraniensis clade (BS =95), 6 with the L. pseudotheobromae clade (BS $=100)$, and 1 with the L. parva clade (BS =99).
Dieback and corky bark symptoms on rambutan. Vascular necrosis (Fig. 3B and C) and necrosis of branches (Fig. 3A) were observed 8 DAI. At 14 DAI, dieback was observed: diseased branches turned from light brown to dark brown, starting from the inoculated area and spreading to the leaves (Fig. 3D). The main stems turned light brown to dark brown, with vascular necrosis that eventually caused the death of the plant (Figs. 3C and 4C). At 30 DAI,

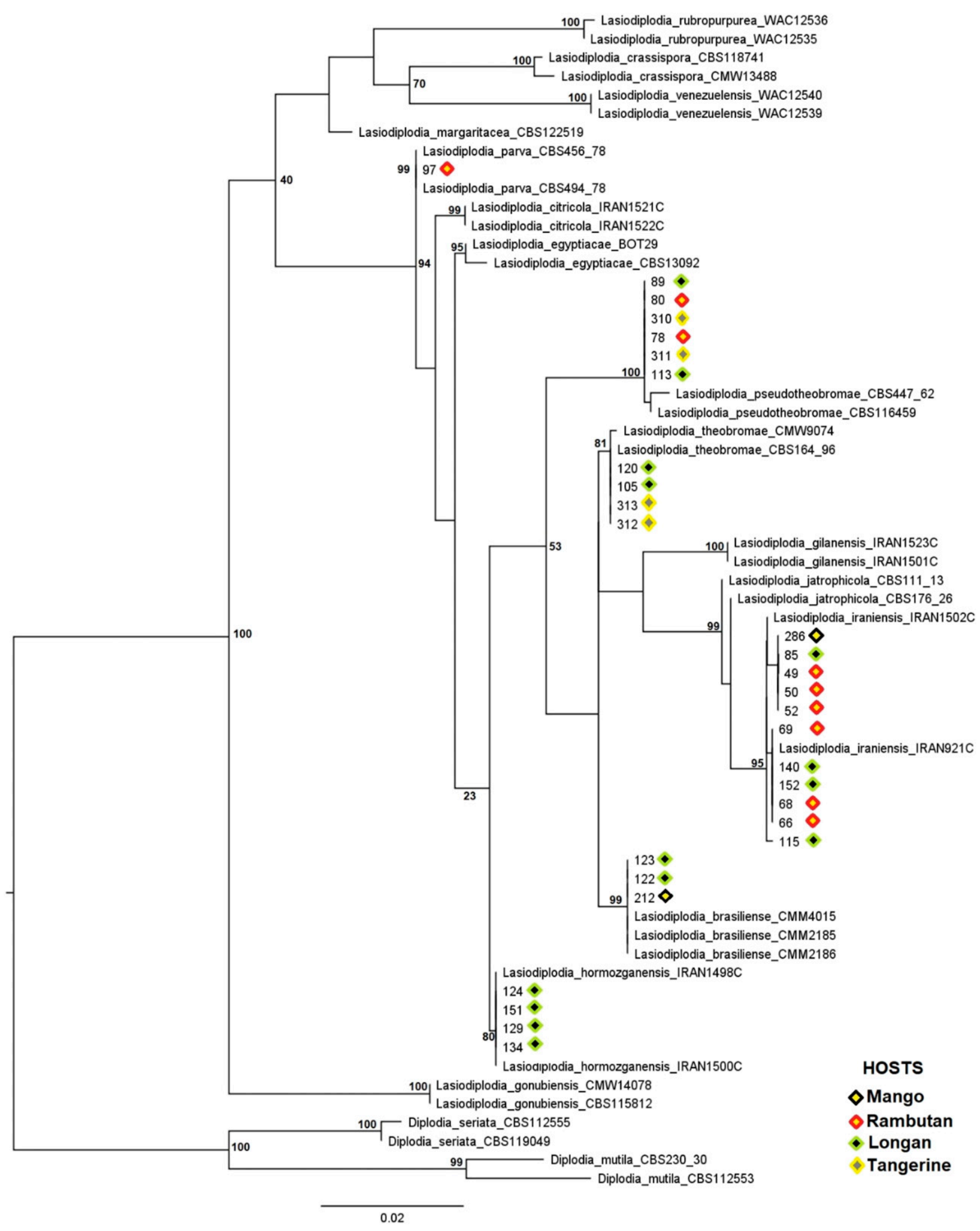

Fig. 2. Best maximum-likelihood tree of genus Lasiodiplodia based on the concatenated sequences of $\beta$-tubulin, internal transcribed spacer, and translation elongation factor EF1- $\alpha$. Bootstrap support values are shown at the nodes and isolates and hosts used in this study are marked. The tree was rooted to the outgroups Diplodia seriata (CBS 119049 and CBS 112555) and D. mutila (CBS 230.30 and CBS 112553). 
light brown pycnidia were observed on branches and main stems, turning dark brown with age. Corky bark symptoms were observed 60 DAI (Fig. 5). Control seedlings inoculated with PDA disks showed no symptoms of dieback.

Of the 39 isolates of Botryosphaeriaceae evaluated, 13 caused dieback on rambutan (Table 3). Of these, three isolates were collected from rambutan showing fruit rot and one from rambutan with dieback, two from longan with fruit rot, one from longan and three from mango with inflorescence blight, and three from tangerine with dieback (Fig. 4). Seven species (L. brasiliensis, L. hormozganensis, L. iraniensis, L. pseudotheobromae, L. theobromae, $N$. parvum, and N. batangarum) caused dieback on rambutan in Puerto Rico. All Lasiodiplodia spp. and Neofusicoccum spp. were reisolated from pathogenicity tests, fulfilling Koch's postulates.

Dieback and corky bark symptoms on longan. Of the 39 isolates of Botryosphaeriaceae evaluated, cross inoculations showed that 10 isolates caused dieback on longan (Table 3). Of these, three isolates were from rambutan causing leaf blight and dieback symptoms, three from longan with fruit rot and inflorescence blight, one from mango with inflorescence blight, and three from tangerine with dieback on branches (Fig. 6). Isolates 124, 129, 66, and 313 caused dieback at 8 DAI and the remaining isolates caused dieback at 14 DAI. At 30 DAI, light-brown pycnidia that turned dark brown with age developed on the branches and trunk. Corky bark symptoms were observed on longan branches at 60 DAI (Fig. 5). No symptoms were observed in control seedlings. Four species belonging to the Botryosphaeriaceae family
(L. hormozganensis, L. iraniensis, L. pseudotheobromae, and L. theobromae) caused dieback of longan. All four Lasiodiplodia spp. were reisolated from pathogenicity tests, fulfilling Koch's postulates.

The difference in number of isolates causing dieback on rambutan versus longan was not significant (Fisher's exact test, $P=0.62$ ). The proportion of pathogenic isolates did not differ significantly among original hosts (rambutan, longan, mango, and tangerine, $P=0.18$ ). Similarly, the number of pathogenic isolates obtained from different organs (leaf, fruit, branch, and inflorescence) did not differ significantly $(P=0.28)$.

\section{Discussion}

Maximum-likelihood analysis supported identification of nine species in the Botryosphaeriaceae family among the fungi isolated from tropical fruit trees with a variety of symptoms. Five of these belong to the genus Lasiodiplodia (L. brasiliensis, L. hormozganensis, L. iraniensis, L. pseudotheobromae, and L. theobromae) and three to genus Neofusicoccum (N. batangarum, N. mangiferae, and $N$. parvum). Only $L$. theobromae has been previously reported causing dieback in rambutan orchards (in Costa Rica), and one Lasiodiplodia sp. was previously reported to cause dieback of longan shoots (in Thailand) (MAG 2007; Sardsud et al. 1998). To our knowledge, this is the first report of L. hormozganensis, L. iraniensis, and L. pseudotheobromae causing dieback and corky bark on rambutan and longan trees, and the first report of $N$. parvum, $N$. batangarum, and L. brasiliensis causing dieback and corky bark on rambutan.
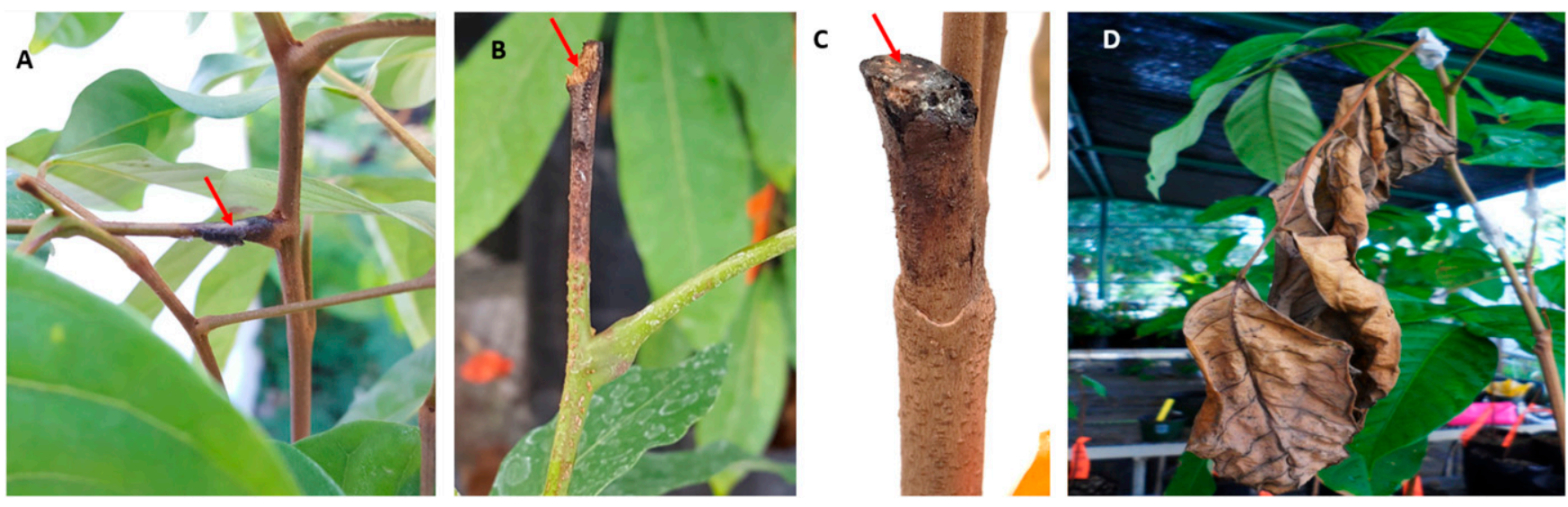

Fig. 3. Branch necrosis, vascular necrosis, and dieback on rambutan. A, Branch necrosis at 8 days after inoculation (DAl); B and C, vascular necrosis at 8 DAl; and D, dieback at 14 DAl.

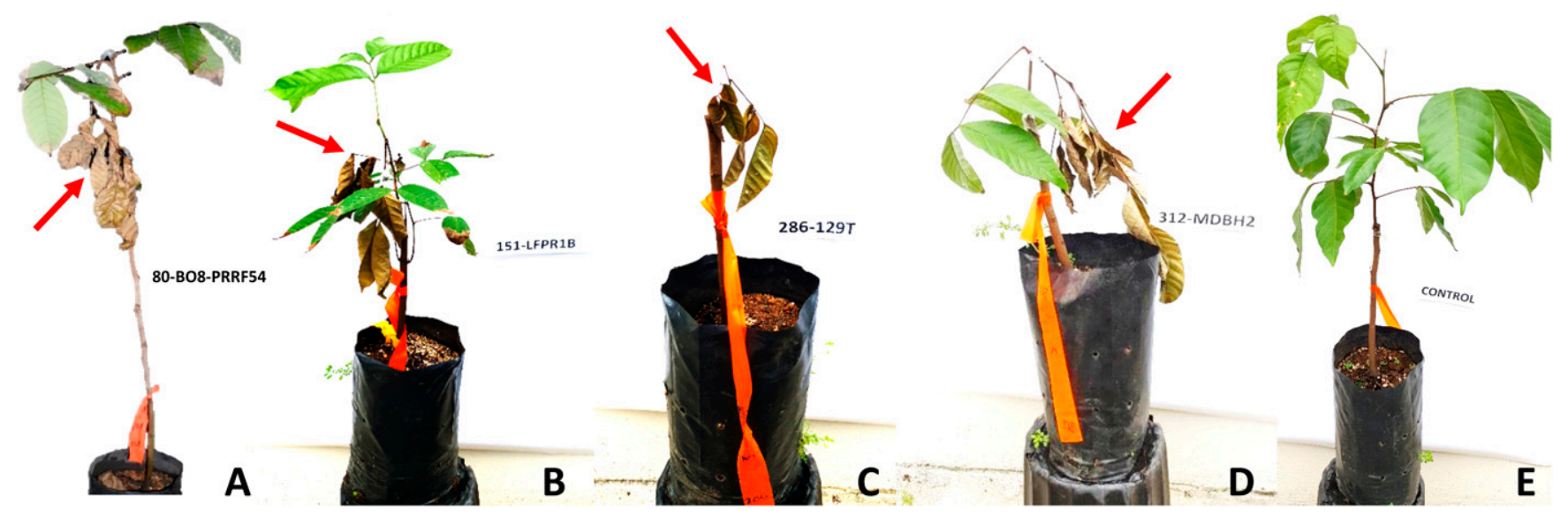

Fig. 4. Dieback on 1-year-old rambutan seedlings caused by Botryosphaeriaceae isolates obtained from dieback, fruit rot, and inflorescence blight of A, rambutan; $\mathbf{B}$, longan; C, mango; $\mathbf{D}$, tangerine; and $\mathbf{E}$, control. Arrows show dieback at 14 days after inoculation. 
Of the nine species tested, seven (L. brasiliensis, L. hormozganensis, L. iraniensis, L. pseudotheobromae, L. theobromae, N. batangarum, and $N$. parvum) caused dieback on rambutan in Puerto Rico and only four $(L$. hormozganensis, L. iraniensis, L. pseudotheobromae, and L. theobromae) caused dieback in longan. Although longan and rambutan are closely related members of the same family, our findings suggest greater resistance of longan trees to species of Botryosphaeriaceae compared with rambutan.

Analysis of the longan genome has revealed more pathogen resistance genes in the nucleotide-binding site leucine-rich repeat (NBSLRR) and LRR receptor-like kinase (RLK) families than in other fruit such as grape, kiwifruit, mei (Myrica rubra), orange, papaya, and peach (Morales-Cruz et al. 2015; Yuling et al. 2017). Higher expression or greater diversity of resistance proteins in longan could explain resistance of longan against Botryosphaeriaceae isolates. Several studies showed that NBS-LRR and LRR-RLK genes conferred resistance in a variety of plants, including Arabidopsis, rice, peanut, wheat, and barley, against pathogens such as Erysiphe cruciferarum, E. cichoracearum, Magnaporthe oryzae, Aspergillus flavus, and Fusarium graminearum, respectively (Chen et al. 2015; Fukuoka et al. 2014; Ma et al. 2015; Song et al. 2017; Thapa et al. 2018; Xiao et al. 2001; Yang et al. 2013; Zhang et al. 2015). However, more studies need to be conducted to elucidate which genes in longan are responsible for resistance to Neofusicoccum spp.

Cross inoculations showed that species in the Botryosphaeriaceae family have a broad host range in tropical fruit crops. Isolates of Botryosphaeriaceae collected from mango, longan, and tangerine were pathogenic on rambutan, and isolates collected from mango, rambutan, and tangerine were pathogenic on longan. L. theobromae and $N$. parvum are known to have broad host ranges, including tropical and subtropical fruit crops (Khanzada et al. 2004; Punithalingam 1976; Sakalidis et al. 2013; Slippers and Wingfield 2007). Worldwide, over 500 hosts for L. theobromae (Punithalingam 1976, 1980) and 90 hosts for $N$. parvum have been reported (Sakalidis et al. 2013; Slippers and Wingfield 2007).

In previous reports, these fungi were identified using morphology alone; a phylogenetic species concept based on DNA sequence data was not applied until recently. With the addition of DNA sequence data, several new species have been identified in the L. theobromae and $N$. parvum/N. ribis complexes (Abdollahzadeh et al. 2010; Alves et al. 2008; Burgess et al. 2006; Ismail et al. 2012; Pavlic et al. 2009a,b; Sakalidis et al. 2013). It is probable that some of the studies mentioned above might today be referred to the L. theobromae and $N$. parvum species complexes rather than the species sensu stricto. It is possible that these species complexes include several species with narrow host ranges rather than one species with a broad host range. This is the case for L. iraniensis, L. pseudotheobromae, L. hormozganensis, and L. brasiliensis, which recently were identified within the $L$. theobromae complex using DNA sequences. They cause diseases including cankers, dieback, gummosis, necrosis, fruit rot, and stem end rot in economically important plants such as Acacia mangium, Bougainvillea spectabilis, cashew, citrus, coconut, eucalyptus, grape, mango, palm, Ricinus communis, and Salvadora persica (Abdollahzadeh et al. 2010; Al-Sadi et al. 2013; Castro-Medina et al. 2014; Custódio et al. 2018; Dissanayake et al. 2015; Ismail et al. 2012; Kwon et al. 2017; Li et al. 2015; Marques et al. 2013a; Munirah et al. 2017; Rodríguez-Gálvez et al. 2017; Rosado and Machado 2016; Sakalidis et al. 2011).

Many fungi of the Botryosphaeriaceae family are endophytes, becoming pathogens when the host is stressed by environmental factors (Chethana et al. 2016; Félix et al. 2016; Paolinelli-Alfonso et al. 2016; Slippers and Wingfield 2007; Yan et al. 2018). For example, L. theobromae is an opportunistic pathogen of woody plants that increases in virulence at high temperatures, producing cellulases and lignocellulases, 18 chitin-binding gene families, and heat-shock proteins. These enzymes and proteins allow the fungus to colonize plant
A

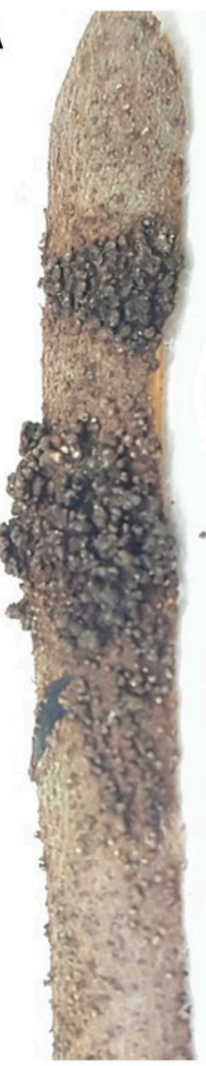

B

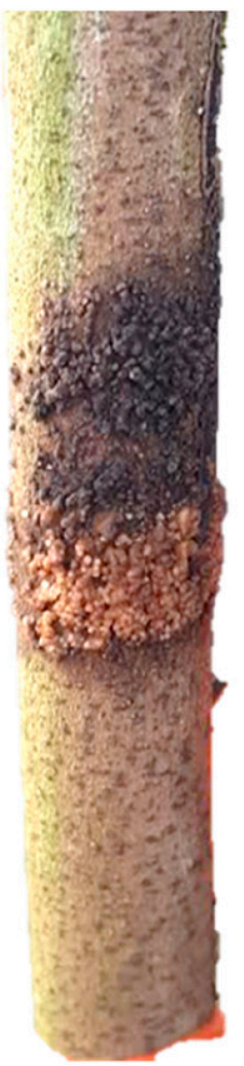

C

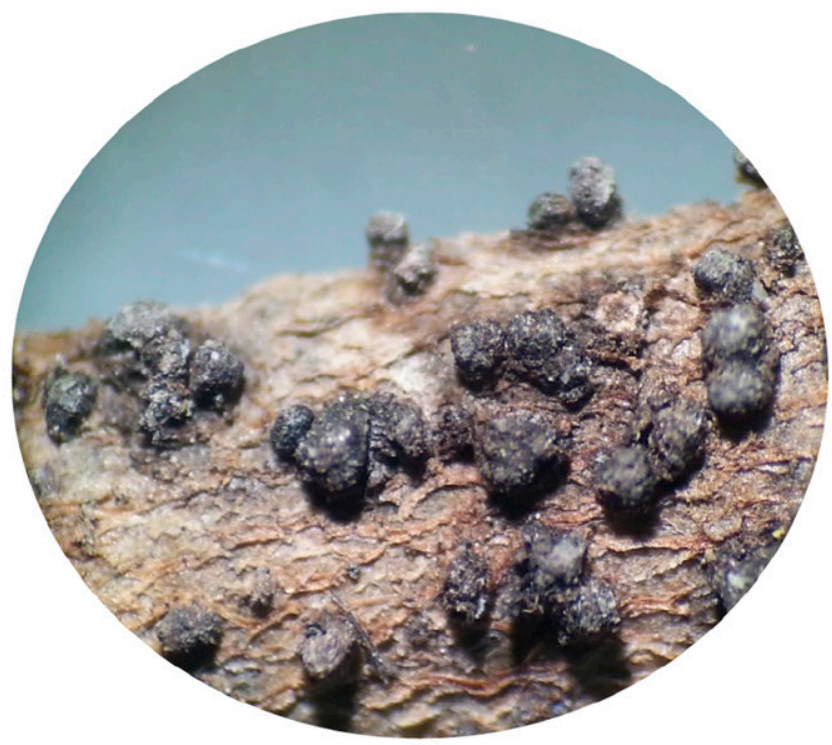

Fig. 5. Corky bark symptoms on rambutan and longan branches at 60 days after inoculation. A, Corky bark symptoms on rambutan; B, corky bark symptoms on longan; and C, profuse pycnidia production on branches. 
tissue through degradation of the cell wall and protection from host defense (Félix et al. 2016; Paolinelli-Alfonso et al. 2016; Yan et al. 2018). Recently, analysis of Botryosphaeriaceae genomes (Botryosphaeria dothidea, L. theobromae, and N. parvum) revealed cytochrome $\mathrm{P} 450$ mono-oxygenase genes, involved in fungal adaptation to new ecological niches. These genes can provide protection during the infection through the detoxification of phytotoxins (Chen et al. 2014; Yan et al. 2018).

Table 3. Botryosphaeriaceae isolates that caused dieback on rambutan and longan

\begin{tabular}{|c|c|c|c|c|}
\hline Isolates & Fungi & Source & $\begin{array}{l}\text { Dieback in } \\
\text { rambutan }\end{array}$ & $\begin{array}{c}\text { Dieback in } \\
\text { longan }\end{array}$ \\
\hline 49.Bt8-RH23B & Lasiodiplodia iraniensis & Rambutan leaves & No & No \\
\hline 50.Bt9-RH25 & L. iraniensis & Rambutan leaves & No & Yes \\
\hline 52.Bt21-RH8 & L. iraniensis & Rambutan leaves & No & No \\
\hline 80.BO8-PRRF58 & L. pseudotheobromae & Rambutan fruit & Yes & No \\
\hline 97.BO11-PRRF54 & L. parva & Rambutan fruit & No & No \\
\hline 2. BO2-PRRF35 & Neofusicoccum parvum & Rambutan fruit & Yes & No \\
\hline 6.BO6-PRRF64 & N. parvum & Rambutan fruit & Yes & No \\
\hline 253.RFISAB4 & N. batangarum & Rambutan fruit & No & No \\
\hline 254.RFISAB2 & N. batangarum & Rambutan fruit & No & No \\
\hline 255.RFISAJIJ3 & N. mangiferae & Rambutan fruit & No & No \\
\hline 78.Bt23-RC8C & L. pseudotheobromae & Rambutan branches & No & No \\
\hline 66.Bt3-RC6A & L. iraniensis & Rambutan branches & No & Yes \\
\hline 68.Bt5-RC4B & L. iraniensis & Rambutan branches & No & No \\
\hline 69.Bt6-RC2B & L. iraniensis & Rambutan branches & Yes & Yes \\
\hline 89. PHLO6 & L. pseudotheobromae & Longan inflorescences & No & No \\
\hline 113.FLLOPR3 & L. pseudotheobromae & Longan inflorescences & No & No \\
\hline 105.PHLO9 & L. theobromae & Longan inflorescences & No & No \\
\hline 120.FLLOPR5 & L. theobromae & Longan inflorescences & No & No \\
\hline 85.PHLO2 & L. iraniensis & Longan inflorescences & No & No \\
\hline 115.FLLOPR 1 & L. iraniensis & Longan inflorescences & No & Yes \\
\hline 122.FLLOPRC1 & L. brasiliensis & Longan inflorescences & Yes & No \\
\hline 123.FLLOPRC2 & L. brasiliensis & Longan inflorescences & No & No \\
\hline 124.LFPR2B & L. hormozganensis & Longan fruit & No & Yes \\
\hline 129.LFPR6B & L. hormozganensis & Longan fruit & Yes & Yes \\
\hline 151.LFPR1B & L. hormozganensis & Longan fruit & Yes & No \\
\hline 134.LFPR12A & L. hormozganensis & Longan fruit & No & No \\
\hline 140.LFPR11A & L. iraniensis & Longan fruit & No & No \\
\hline 152.Bt33-LFPR3 & L. iraniensis & Longan fruit & No & No \\
\hline 212.FLMAISA8 & L. brasiliensis & Mango inflorescences & No & No \\
\hline $286.129 \mathrm{~T}$ & L. iraniensis & Mango inflorescences & Yes & Yes \\
\hline 43.K15C & N. parvum & Mango inflorescences & No & No \\
\hline $294.405 \mathrm{~T}$ & N. parvum & Mango inflorescences & Yes & No \\
\hline $284.25 \mathrm{P}$ & N. batangarum & Mango inflorescences & No & No \\
\hline $295.317 \mathrm{~T}$ & N. batangarum & Mango inflorescences & Yes & No \\
\hline $302.230 \mathrm{~T}$ & N. batangarum & Mango inflorescences & No & No \\
\hline 310.MDBH3 & L. pseudotheobromae & Tangerine branches & Yes & Yes \\
\hline 311.MDB51 & L. pseudotheobromae & Tangerine branches & Yes & Yes \\
\hline 312.MDBH2 & L. theobromae & Tangerine branches & Yes & No \\
\hline 313.MDBH4 & L. theobromae & Tangerine branches & No & Yes \\
\hline
\end{tabular}

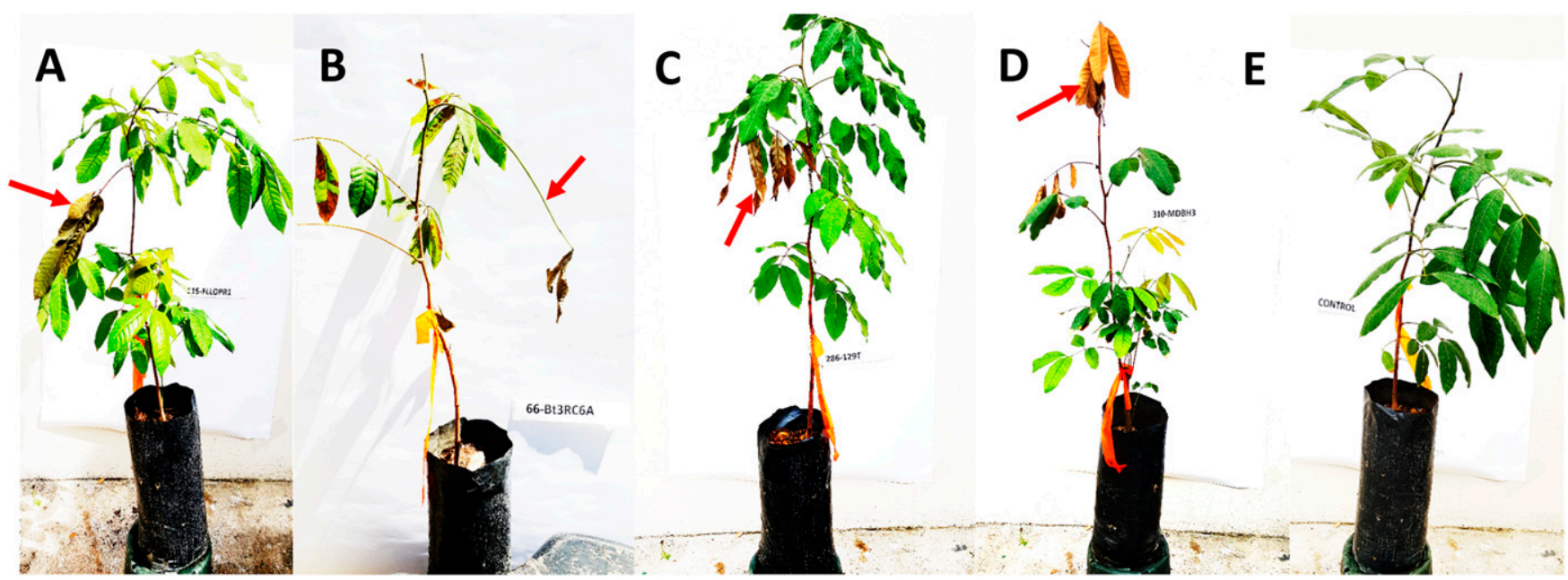

Fig. 6. Dieback on 1-year-old longan seedlings caused by Botryosphaeriaceae isolates obtained from dieback, fruit rot and inflorescence blight of A, longan; B, rambutan; C, mango; $\mathbf{D}$, tangerine; and $\mathbf{E}$, control. Arrows show dieback at 14 days after inoculation. 
This study confirms our hypothesis that a variety of species in the Botryosphaeriaceae family can cause vascular necrosis, dieback, and corky bark in rambutan and longan in Puerto Rico. Pathogenicity of Dolabra nepheliae (previously identified as the pathogen responsible for corky bark of rambutan) needs to be proven to determine whether this species can also cause corky bark symptoms on rambutan and longan, or if it is a saprotroph feeding on dead organic material left by infections caused by species of Botryosphaeriaceae.

Cross-inoculation with Lasiodiplodia and Neofusicoccum isolates from different hosts showed that pathogenicity is wide spectrum. In Puerto Rico, the combination of high humidity, high temperatures, wounds caused by wind damage, and proximity among fruit tree crops could facilitate cell penetration and degradation by Lasiodiplodia and Neofusicoccum spp. and movement between crops. These adaptations to different hosts by isolates of Botryosphaeriaceae indicate that different planting alternatives (for example, annual crops intercalated with woody plants) should be considered for better crop management. The corky bark symptoms observed in the field are the reproductive structures of the Botryosphaeriaceae spp.; therefore, drip irrigation is the best way to avoid dispersion of the pathogen from one tree to another. Because members of the Botryosphaeriaceae family are vascular pathogens, wounds left in the pruning process can facilitate their entrance. These Botryosphaeriaceae fungi are very virulent pathogens with wide host ranges; thus, better management practices for planting, pruning, and irrigation of rambutan, longan, mango, and tangerine are needed in Puerto Rico and worldwide.

\section{Literature Cited}

Abdollahzadeh, J., Javadi, A., Mohammadi-Goltapeh, E., Zare, R., and Phillips, A. J. L. 2010. Phylogeny and morphology of four new species of Lasiodiplodia from Iran. Persoonia 25:1-10.

Abdollahzadeh, J., Zare, R., and Phillips, A. J. 2013. Phylogeny and taxonomy of Botryosphaeria and Neofusicoccum species in Iran, with description of Botryosphaeria scharifii sp. nov. Mycologia 105:210-220.

Adesemoye, A. O., Mayorquin, J. S., Wang, D. H., Twizeyimana, M., Lynch, S. C., and Eskalen, A. 2014. Identification of species of Botryosphaeriaceae causing bot gummosis in citrus in California. Plant Dis. 98:55-61.

Al-Sadi, A. M., Al-Wehaibi, A. N., Al-Shariqi, R. M., Al-Hammadi, M. S., Al-Hosni, I. A., Al-Mahmooli, I. H., and Al-Ghaithi, A. G. 2013. Population genetic analysis reveals diversity in Lasiodiplodia species infecting date palm, citrus, and mango in Oman and the UAE. Plant Dis. 97:1363-1369.

Altendorf, S. 2018. Minor tropical fruits. Pages 67-75 in: Food Outlook. FAO. http:// www.fao.org/fileadmin/templates/est/COMM_MARKETS_MONITORING/ Tropical_Fruits/Documents/Minor_Tropical_Fruits_FoodOutlook_1_2018. pdf

Alves, A., Correia, A., Luque, J., and Phillips, A. J. L. 2004. Botryosphaeria corticola sp. nov. on Quercus species, with notes and description of Botryosphaeria stevensii and its anamorph Diplodia mutila. Mycologia 96: 598-613.

Alves, A., Crous, P. W., Correia, A., and Phillips, A. J. L. 2008. Morphological and molecular data reveal cryptic speciation in Lasiodiplodia theobromae. Fungal Divers. 28:1-13.

Booth, C., and Ting, W. P. 1964. Dolabra Nepheliae gen. nov., sp. nov., associated with canker of Nephelium lappaceum. Trans. Br. Mycol. Soc. 47:235-237.

Borhan, M. H., Holub, E. B., Kindrachuk, C., Omidi, M., Bozorgmanesh-Frad, G., and Rimmer, S. R. 2010. WRR4, a broad-spectrum TIR-NBS-LRR gene from Arabidopsis thaliana that confers white rust resistance in transgenic oilseed brassica crops. Mol. Plant Pathol. 11:283-291.

Burgess, T. I., Barber, P. A., Mohali, S., Pegg, G., de Beer, W., and Wingfield, M. J. 2006. Three new Lasiodiplodia spp. from the tropics, recognized based on DNA sequence comparisons and morphology. Mycologia 98:423-435.

Burruano, S., Mondello, V., Conigliaro, G., Alfonzo, A., Spagnolo, A., and Mugnai, L. 2008. Grapevine decline in Italy caused by Lasiodiplodia theobromae. Phytopathol. Mediterr. 47:132-136.

Carbone, I., and Kohn, L. M. 1999. A method for designing primer set for speciation studies in filamentous ascomycetes. Mycologia 91:553-556.

Castro-Medina, F., Mohali, R. S., Úrbez-Torres, J. R., and Gubler, W. D. 2014. First report of Lasiodiplodia pseudotheobromae causing trunk cankers in Acacia mangium in Venezuela. Plant Dis. 98:686.

Chamswarng, C., Punnawich, Y., and Warin, I. 2012. Fungal disease control and postharvest quality during storage of rambutan (Nephelium lappaceum L. cv. Rong-Rien) fruits treated with preharvest application of Trichoderma harzianum and chelated calcium. Philipp. Agric. Sci. 95: 312-316.
Chen, J., Peng, P., Tian, J., He, Y., Zhang, L., Liu, Z., Yin, D., and Zhang, Z. 2015. Pike, a rice blast resistance allele consisting of two adjacent NBS-LRR genes, was identified as a novel allele at the pik locus. Mol. Breed. 35:117.

Chen, W., Lee, M. K., Jefcoate, C., Kim, S. C., Chen, F., and Yu, J. H. 2014. Fungal cytochrome p450 monooxygenases: Their distribution, structure, functions, family expansion, and evolutionary origin. Genome Biol. Evol. 6:1620-1634.

Chethana, K. W. T., Li, X. H., Zhang, W., Hyde, K. D., and Yan, J. Y. 2016. Trai decryption of molecular research on Botryosphaeriaceae in woody plants. Phytopathol. Mediterr. 55:147-171.

Crane, J. H., Zee, F., Bender, G. S., Faber, B., Brunner, B., and Chia, C. L. 2005 Commercial sapindaceous fruit production in the USA. Acta Hortic. 665 93-104.

Custódio, F. A., Machado, A. R., Soares, D. J., Soares, D. J., and Pereira, O. L. 2018. Lasiodiplodia hormozganensis causing basal stem rot on Ricinus communis in Brazil. Australas. Plant Dis. Notes 13:25.

Dissanayake, A. J., Zhang, W., Mei, L., Chukeatirote, E., Yan, J. Y., Li, X. H., and Hyde, K. D. 2015. Lasiodiplodia pseudotheobromae causes pedicel and peduncle discolouration of grapes in China. Australas. Plant Dis. Notes 10:21.

Farungsang, U., Sangchote, S., and Farungsang, N. 1992. Appearance of quiescent fruit rot fungi on rambutan stored at $13^{\circ} \mathrm{C}$ and $25^{\circ} \mathrm{C}$. Acta Hortic. $321: 903-907$.

Félix, C., Duarte, A. S., Vitorino, R., Guerreiro, A. C. L., Domingues, P., Correia A. C. M., Alves, A., and Esteves, A. C. 2016. Temperature modulates the secretome of the phytopathogenic fungus Lasiodiplodia theobromae. Front. Plant Sci. 7:1-12.

Fukuoka, S., Yamamoto, S. I., Mizobuchi, R., Yamanouchi, U., Ono, K. Kitazawa, N., Yasuda, N., Fujita, Y., Thi, T., Nguyen, T., Koizumi, S., Sugimoto, K., Matsumoto, T., and Yano, M. 2014. Multiple functional polymorphisms in a single disease resistance gene in rice enhance durable resistance to blast. Sci. Rep. 4: Article 4550.

Glass, N. L., and Donaldson, G. C. 1995. Development of primer sets designed for use with the PCR to amplify conserved genes from filamentous ascomycetes Appl. Environ. Microbiol. 61:1323-1330.

Goenaga, R., and Jenkins, D. 2011. Yield and fruit quality traits of rambutan cultivars grafted onto a common rootstock and grown at two locations in Puerto Rico. HortTechnology 21:136-140.

Inderbitzin, P., Bostock, R. M., Trouillas, F. P., and Michailides, T. J. 2010. A sixlocus phylogeny reveals high species diversity in Botryosphaeriaceae from California almond. Mycologia 102:1350-1368

Ismail, A. M., Cirvilleri, G., Polizzi, G., Crous, P. W., Groenewald, J. Z., and Lombard, L. 2012. Lasiodiplodia species associated with dieback disease of mango (Mangifera indica) in Egypt. Australas. Plant Pathol. 41:649-660.

Javier-Alva, J., Gramaje, D., Alvarez, L. A., and Armengol, J. 2009. First report of Neofusicoccum parvum associated with dieback of mango trees in Peru. Plant Dis. 93:426.

Katoh, K., and Standley, D. M. 2013. MAFFT multiple sequence alignment software version 7: improvements in performance and usability. Mol. Biol. Evol. 30:772-780.

Khanzada, M. A., Lodhi, A. M., and Shahzad, S. 2004. Pathogenicity of Lasiodiplodia theobromae and Fusarium solani on mango. Pak. J. Bot. 36:181-189.

Kwon, J.-H., Choi, O., Kang, B., Lee, Y., Park, J., Kang, D.-W., Han, I., and Kim, J. 2017. Identification of Lasiodiplodia pseudotheobromae causing mango dieback in Korea. Can. J. Plant Pathol. 39:241-245.

Li, G., Arnold, R. J., Liu, F., Li, J., and Chen, S. 2015. Identification and pathogenicity of Lasiodiplodia species from Eucalyptus urophylla $\times$ grandis, Polyscias balfouriana and Bougainvillea spectabilis in Southern China. J. Phytopathol. 163:956-967.

Lombard, L., Serrato-Diaz, L. M., Cheewangkoon, R., French-Monar, R. D. Decock, C., and Crous, P. W. 2014. Phylogeny and taxonomy of the genus Gliocephalotrichum. Persoonia 32:127-140.

Ma, J., Lei, C., Xu, X., Hao, K., Wang, J., Cheng, Z., Ma, X., Ma, J., Zhou, K., Zhang, X., Guo, X., Wu, F., Lin, Q., Wang, C., Zhai, H., Wang, H., and Wan, J. 2015. Pi64, encoding a novel CC-NBS-LRR protein, confers resistance to leaf and neck blast in rice. Mol. Plant-Microbe Interact. 28:558-568.

MAG. 2007. Plan Estratégico de la cadena productiva del rambután. Ministerio de Agricultura y Ganaderia de Costa Rica. http://www.mag.go.cr/bibliotecavirtual/ E70-4288.pdf

Marques, M. W., Lima, N. B., de Morais, M. A., Jr., Barbosa, M. A., Souza, B. O., Michereff, S. J., Phillips, A. J., and Câmara, M. P. 2013a. Species of Lasiodiplodia associated with mango in Brazil. Fungal Divers. 61:181-193.

Marques, M. W., Lima, N. B., de Morais, M. A., Jr., Michereff, S. J., Phillips, A. J. L., and Câmara, M. P. S. 2013b. Botryosphaeria, Neofusicoccum, Neoscytalidium and Pseudofusicoccum species associated with mango in Brazil. Fungal Divers. 61:195-208.

Mayorquin, J. S., Wang, D. H., Twizeyimana, M., and Eskalen, A. 2016 Identification, distribution, and pathogenicity of Diatrypaceae and Botryosphaeriaceae associated with citrus branch canker in the southern California desert. Plant Dis. 100:2402-2413.

McDonald, V., and Eskalen, A. 2011. Botryosphaeriaceae species associated with avocado branch cankers in California. Plant Dis. 95:1465-1473

Michailides, T. J., Morgan, D. P., and Felts, D. 2002. First report of Botryosphaeria rhodina causing shoot blight of pistachio in California. Plant Dis. 86:1273. 
Miller, M. A., Pfeiffer, W., and Schwartz, T. 2010. Creating the CIPRES Science Gateway for inference of large phylogenetic trees. Pages 1-8 in: Proc. Gateway Comput. Environ. Workshop (GCE), New Orleans, LA, U.S.A.

Morales-Cruz, A., Amrine, K. C. H., Blanco-Ulate, B., Lawrence, D. P., Travadon, R., Rolshausen, P. E., Baumgartner, K., and Cantu, D. 2015. Distinctive expansion of gene families associated with plant cell wall degradation, secondary metabolism, and nutrient uptake in the genomes of grapevine trunk pathogens. BMC Genomics 16: Article 469.

Muhammad, S., Zafar, I., Ahmad, S., and Muhammad, A. A. 2009. Association of Lasiodiplodia theobromae with different decline disorders in mango (Mangifera indica L.). Pak. J. Bot. 41:359-368.

Munirah, M. S., Azmi, A. R., Yong, S. Y. C., Ain, N., and Izzati, M. Z. 2017. Characterization of Lasiodiplodia theobromae and L. pseudotheobromae causing fruit rot on pre-harvest mango in Malaysia. Plant Pathol. Quar. 7: 202-213.

Nishijima, K. A., Follett, P. A., Bushe, B. C., and Nagao, M. A. 2002. First report of Lasmenia sp. and two species of Gliocephalotrichum on rambutan in Hawaii. Plant Dis. 86:71.

Paolinelli-Alfonso, M., Villalobos-Escobedo, J. M., Rolshausen, P., HerreraEstrella, A., Galindo-Sánchez, C., López-Hernández, J. F., and HernandezMartinez, R. 2016. Global transcriptional analysis suggests Lasiodiplodia theobromae pathogenicity factors involved in modulation of grapevine defensive response. BMC Genomics 17:615.

Pavlic, D., Slippers, B., Coutinho, T. A., and Wingfield, M. J. 2009a. Multiple gene genealogies and phenotypic data reveal cryptic species of the Botryosphaeriaceae: A case of study on the Neofusicoccum parvum $/ N$. ribis complex. Mol. Phylogenet. Evol. 51:259-268.

Pavlic, D., Slippers, B., Coutinho, T. A., and Wingfield, M. J. 2009b. Molecular and phenotypic characterization of three phylogenetic species discovered within the Neofusicoccum parvum/N. ribis complex. Mycologia 101:636-647.

Phillips, A. J. L., Alves, A., Abdollahzadeh, J., Slippers, B., Wingfield, M. J., Groenewald, J. Z., and Crous, P. W. 2013. The Botryosphaeriaceae: Genera and species known from culture. Stud. Mycol. 76:51-167.

Ploetz, R. C. 2003. Diseases of Tropical Fruit Crops. CAB International, Wallingford, U.K.

Polizzi, G., Aiello, D., Vitale, A., Giuffrida, F., Groenewald, J. Z., and Crous, P. W. 2009. First report of shoot blight, canker, and gummosis caused by Neoscytalidium dimidiatum on citrus in Italy. Plant Dis. 93:1215.

Pordesimo, A. N., and Luna-Ilag, L. 1982. Postharvest diseases of mango and rambutan in the Philippines. Pages 211-232 in: Proc. Workshop Mango Rambutan, University of the Philippines at Los Banos, Philippines.

Punithalingam, E. 1976. Botryodiplodia theobromae. Commonwealth Mycological Institute, Kew, Surrey, U.K.

Punithalingam, E. 1980. Plant Diseases Attributed to Botryodiplodia theobromae. Commonwealth Mycological Institute, Kew, Surrey, U.K.

Rodríguez-Gálvez, E., Guerrero, P., Barradas, C., Crous, P. W., and Alves, A. 2017. Phylogeny and pathogenicity of Lasiodiplodia species associated with dieback of mango in Peru. Fungal Biol. 121:452-465.

Rosado, A. W. C., and Machado, A. R. 2016. Phylogeny, identification, and pathogenicity of Lasiodiplodia associated with postharvest stem-end rot of coconut in Brazil. Plant Dis. 100:561-568.

Rossman, A., Melgar, J., Walker, D., Gonzalez, A., Ramirez, T., and Rivera, J. 2012. First report of Dolabra nepheliae associated with corky bark disease of rambutan and pulasan in Honduras. Plant Dis. 96:765.

Rossman, A. Y., Goenaga, R., and Keith, L. 2007. First report of Dolabra nepheliae on rambutan and litchi in Hawaii and Puerto Rico. Plant Dis. 91: 1685.

Rossman, A. Y., Schoch, C. L., Farr, D. F., Nishijima, K., Keith, L., and Goenaga, R. 2010. Dolabra nepheliae on rambutan and lychee represents a novel lineage of phytopathogenic Eurotiomycetes. Mycoscience 51:300-309.

Sakalidis, M. L., Ray, J. D., Lanoiselet, V., Hardy, G. E., and Burgess, T. I. 2011. Pathogenic Botryosphaeriaceae associated with Mangifera indica in the Kimberley Region of Western Australia. Eur. J. Plant Pathol. 130:379-391.

Sakalidis, M. L., Slippers, B., Wingfield, B. D., Hardy, G. E. S. J., and Burgess, T. I. 2013. The challenge of understanding the origin, pathways and extent of fungal invasions: Global populations of the Neofusicoccum parvum-N. ribis species complex. Diversity Distrib. 19:873-883.

Sangchote, S., Farungsang, U., and Farungsang, N. 1998. Pre- and postharvest infection of rambutan by pathogens and effects of post-harvest treatments. Pages 87-91 in: Disease Control and Storage Life Extension in Fruit, Proc. Int. Workshop, Chiang Mai, Thailand. L. M. Coates, P. J. Hofman, and G. I. Johnson, eds. Australian Centre for International Agricultural Research. Canberra, Australia.

Sardsud, V., Sttigul, C., Sarsud, U., Chantrasri, P., and Promin, S. 1998. Pages 147-152 in: Endophytic Fungi in Longan. Australian Center for International Agricultural Research, Canberra, Australia.

Serrato-Diaz, L. M., Latoni-Brailowsky, E. I., Rivera-Vargas, L. I., Goenaga, R. J., Crous, P. W., and French-Monar, R. D. 2013a. First report of Calonectria hongkongensis causing fruit rot of rambutan (Nephelium lappaceum L.). Plant Dis. 97:1117.

Serrato-Diaz, L. M., Latoni-Brailowsky, E. I., Rivera-Vargas, L. I., Goenaga, R. J., and French-Monar, R. D. 2012. First report of Gliocephalotrichum bulbilium and G. simplex causing fruit rot of rambutan in Puerto Rico. Plant Dis. 96:1225.
Serrato-Diaz, L. M., Perez-Cuevas, M., Rivera-Vargas, L. I., Goenaga, R., and French-Monar, R. D. 2015a. First report of Fusarium decemcellulare causing inflorescence wilt and vascular and flower necrosis of rambutan (Nephelium lappaceum), longan (Dimocarpus longan), and mango (Mangifera indica). Plant Dis. 99:1187.

Serrato-Diaz, L. M., Rivera-Vargas, L. I., and French-Monar, R. D. 2014a. First report of Neofusicoccum mangiferae causing rachis necrosis and Inflorescence blight of mango (Mangifera indica) in Puerto Rico. Plant Dis. 98:570.

Serrato-Diaz, L. M., Rivera-Vargas, L. I., and Goenaga, R. 2010. First report of sooty mold of longan (Dimocarpus longan L.) caused by Tripospermum porosporiferum Matsushima and T. variabile Matsushima in Puerto Rico. J. Agric. Univ. P. R. 94:285-287.

Serrato-Diaz, L. M., Rivera-Vargas, L. I., Goenaga, R. J., and French-Monar, R. D. $2013 \mathrm{~b}$. Identification of the fungal pathogen complex causing fruit rot of rambutan (Nephelium lappaceum L.) in Puerto Rico. (Abstr.) Phytopathology 103:S2.130.

Serrato-Diaz, L. M., Rivera-Vargas, L. I., Goenaga, R. J. and French-Monar, R. D 2013c. The Botryosphaeriaceae, a major player associated with tropical fruit diseases in Puerto Rico. (Abstr.) Phytopathology 103:S3.16.

Serrato-Diaz, L. M., Rivera-Vargas, L. I., Goenaga, R., and French-Monar, R. D. 2014b. First report of Lasiodiplodia theobromae causing inflorescence blight and fruit rot of longan (Dimocarpus longan L.) in Puerto Rico. Plant Dis. 98 279

Serrato-Diaz, L. M., Rivera-Vargas, L. I., Goenaga, R. J. and French-Monar, R. D. 2015b. Fungal pathogen complexes associated with diseases of rambutan, longan and mango in Puerto Rico. (Abstr.) Phytopathology 105:S1.4.

Serrato-Diaz, L. M., Rivera-Vargas, L. I., Goenaga, R. J., Navarro, E. D., and French-Monar, R. D. 2017. First report of Colletotrichum fructicola and C. queenslandicum causing fruit rot of rambutan (Nephelium lappaceum) Plant Dis. 101:1043.

Serrato-Diaz, L. M., Rivera-Vargas, L. I., Goenaga, R. J., Verkley, G. J. M., and French-Monar, R. D. 2011. First report of a Lasmenia sp. Causing rachis necrosis, flower abortion, fruit rot, and leaf spots on rambutan in Puerto Rico. Plant Dis. 95:1313.

Sivakumar, D., Wijeratnam, R. S. W., Wijesundera, R. L. C., and Abeysekera, M. 1997. Post-harvest diseases of rambutan (Nephelium lappaceum) in the western Province. J. Natl. Counc. Sri Lanka 25:225-229.

Sivakumar, D., Wijeratnam, R. S. W., Wijesundera, R. L. C., and Abeysekera, M. 2000. Antagonistic Effect of Trichoderma harzianum on post-harvest pathogens of rambutan (Nephelium lappaceum). Phytoparasitica 28:240.

Slippers, B., and Wingfield, M. J. 2007. Botryosphaeriaceae as endophytes and latent pathogens of woody plants: Diversity, ecology and impact. Fungal Biol. Rev. 21:90-106

Song, H., Wang, P., Li, C., Han, S., Zhao, C., Xia, H., Bi, Y., Guo, B., Zhang, X., and Wang, X. 2017. Comparative analysis of NBS-LRR genes and their response to Aspergillus flavus in Arachis. PLoS One 12:1-14.

Stamatakis, A. 2006a. RAxML-VI-HPC: Maximum likelihood-based phylogenetic analyses with thousands of taxa and mixed models. Bioinformatics 22 2688-2690.

Stamatakis, A. 2006b. Phylogenetic models of rate heterogeneity: A highperformance computing perspective. In: Proc. 20th IEEE/ACM Int. Paralle Distributed Processing Symp. (IPDPS2006), Rhodos, Greece.

Sun, J., Lin, H., Zhang, S., Lin, Y., Wang, H., Lin, M., Hung, Y.-C., and Chen, Y. 2018. The roles of ROS production-scavenging system in Lasiodiplodia theobromae (Pat.) Griff. \& Maubl.-induced pericarp browning and disease development of harvested longan fruit. Food Chem. 247:16-22.

Thapa, G., Gunupuru, L. R., Hehir, J. G., Kahla, A., Mullins, E., and Doohan, F. M. 2018. A pathogen-responsive leucine rich receptor like kinase contributes to Fusarium resistance in cereals. Front. Plant Sci. 9:867.

Úrbez-Torres, J. R., Adams, P., Kamas, J., and Gubler, W. D. 2009. Identification, Incidence, and Pathogenicity of fungal species associated with grapevine dieback in Texas. Am. J. Enol. Vitic. 60:497-507.

Vazquez-Lopez, A., Mora-Aguilera, J. A., Cardenas-Soriano, E., and Teliez-Ortíz, D. 2009. Etiología e histopatología de la muerte descendente de árboles de mamey (Pouteria sapota (Jacq.) h. e. Moore y Stearn) en el Estado de Guerrero, México. Agrociencia 43:717-728

White, T. J., Bruns, T., Lee, S., and Taylor, J. 1990. Amplification and direct sequencing of fungal ribosomal RNA genes for phylogenetics. Pages 315-322 in: PCR Protocols: A Guide to Methods and Applications. M. A Innis, D. H. Gelfand, J. J. Sninsky, and T. J. White, eds. Academic Press, San Diego, CA, U.S.A.

Xiao, S., Ellwood, S., Calis, O., Patrick, E., Li, T., Coleman, M., and Turner, J. G. 2001. Broad-spectrum mildew resistance in Arabidopsis thaliana mediate by RPW8. Science 291:118-120.

Yan, J. Y., Zhao, W. S., Chen, Z., Xing, Q. K., Zhang, W., Chethana, K. W. T., Xue, M. F., Xu, J. P., Phillips, A. J. L., Wang, Y., Liu, J. H., Liu, M., Zhou, Y., Jayawardena, R. S., Manawasinghe, I. S., Huang, J. B., Qiao, G. H., Fu, C. Y., Guo, F. F., Dissanayake, A. J., Peng, Y. L., Hyde, K. D., and Li, X. H. 2018. Comparative genome and transcriptome analyses reveal adaptations to opportunistic infections in woody plant degrading pathogens of Botryosphaeriaceae. DNA Res. 25:87-102. 
Yang, S., Li, J., Zhang, X., Zhang, Q., Huang, J., Chen, J. Q., Hartl, D. L., and Tian, D. 2013. Rapidly evolving R genes in diverse grass species confer resistance to rice blast disease. Proc. Natl. Acad. Sci. U.S.A. 110:18572-18577.

Yang, T., Groenewald, J. Z., Cheewangkoon, R., Jami, F., Abdollahzadeh, J., Lombard, L., and Crous, P. W. 2017. Families, genera, and species of Botryosphaeriales. Fungal Biol. 121:322-346.

Yuling, L., Jiumeng, M., Ruilian, L., Zhangyan, W., Yukun, C., Lili, Y., Chunzhen, C., Yuanchun, J., Qilin, T., Qingfeng, L., Weihua, L., Chengguang, Z., Lixia, L., Yan, H., Dongmin, Z., Minkyaw, T., Zihao, Z., Shengcai, L., Chunshui, Z., Xiaodong, F., Jian, W., Huanming, Y., Rajeev, K. V., Ye, Y., and Zhongxiong, L. 2017. Genome-wide sequencing of longan (Dimocarpus longan Lour.) provides insights into molecular basis of its polyphenol-rich characteristics. Gigascience 6:1-14.

Zea-Bonilla, T., Gonzalez-Sanchez, M. A., Martin-Sanchez, P. M., and PerezJimezez, R. M. 2007. Avocado dieback caused by Neofusicoccum parvum in the Andalucia region, Spain. Plant Dis. 91:1052.

Zhang, X., Yang, S., Wang, J., Jia, Y., Huang, J., Tan, S., Zhong, Y., Wang, L., Gu, L., Chen, J. Q., Pan, Q., Bergelson, J., and Tian, D. 2015. A genomewide survey reveals abundant rice blast R-genes in resistant cultivars. Plant J. $84: 20-28$ 